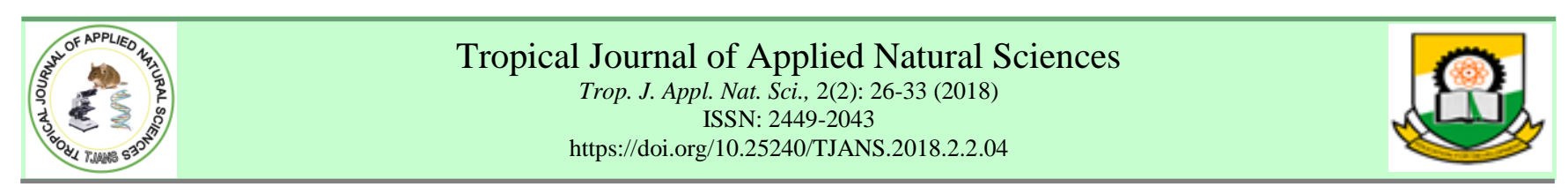

\title{
Effects of aqueous extracts of Gongronema latifolium leaves and Piper guineense seeds on liver and kidney biomarkers of albino rats
}

\author{
Lukong, C. B. ${ }^{1}$, Ifemeje, J. C. ${ }^{1}$, Chukwuka, D. T. ${ }^{1, *}$ and Onah, C. ${ }^{2}$ \\ ${ }^{1}$ Department of Biochemistry, Faculty of Natural Sciences, Chukwuemeka Odumegwu Ojukwu University, Anambra State, Nigeria. \\ ${ }^{2}$ Department of Chemical Pathology, Nnamdi Azikiwe University Teaching Hospital, Nnewi, Anambra State, Nigeria. \\ *Corresponding author's email: integrity3rdtim@gmailcom
}

\begin{abstract}
The effects of administration of aqueous extracts of G. latifolium leaves and Piper guineense seeds on liver and kidney biomarkers of albino rats were studied, and the following parameters were assayed: alkaline phosphatase (ALP), alanine transaminase (ALT), aspartate transaminase (AST), albumin (ALB), electrolytes $\left(\mathrm{Na}^{+}, \mathrm{K}^{+}, \mathrm{Cl}^{-}\right.$and $\left.\mathrm{HCO}_{3}^{-}\right)$, urea and creatinine. 30 animals were divided into 6 groups: Group 1 was control, and $2-6$ were test groups. Only groups 2, 3 and 6 showed significant increase in ALP activity. Moreover, only group 4 showed significant change (decrease) in AST activity. There was a significant decrease in albumin in group 2; whereas serum $\mathrm{Na}^{+}$concentration decreased significantly in group 2, same as $\mathrm{Cl}^{-}$. Urea concentration increased in groups 5 and 6 , whereas $\mathrm{HCO}_{3}^{-}$showed no significant change. Groups 2-4 significantly decreased in creatinine concentration. Thus, aqueous extracts of the samples are safe to the health/functions of the liver of the animals; while they negatively affected the kidneys. The aqueous extract of G. latifolium resulted in negative electrolyte balance, and thus of negative effect to the kidneys. Moreover, a combination of the samples at various concentrations resulted in negative urea clearance, and therefore deleterious to kidney health/functions. The observed significant changes with respect to kidney biomarkers are pointers that aqueous extracts of the samples are of adverse effects to the health and functions of the kidneys of albino rats. This therefore calls for caution in the administration of the samples in traditional medicine preparations, especially when administered in combination.
\end{abstract}

Original Research Article

Received: $11^{\text {th }}$ Dec., 2017

Accepted: $13^{\text {th }}$ Jan., 2018

Published: $14^{\text {th }}$ Mar., 2018

\section{Keywords:}

Gongronemalatifolium

Piperguineense

Biomarkers

liver

kidney.

\section{INTRODUCTION}

$\mathrm{T}$ The American Society for Testing and Materials (2001) remarked that medical herbalism is one of the primary complementary approaches to medicine in many parts of the world. This practice entails the use of either whole plant parts or its extracts. Tietz (1996) remarked that the use of plant extracts for the treatment and prevention of diseases has shown a complete holistic framework of healing.

In the Eastern part of Nigeria, the use of Gongronema latifolium leaves and Piper guineense seeds (and leaves) in food and tradomedicinal preparations dates back to the prehistoric era; and these practices have been passed down to the succeeding generations through oral tradition. These products are used by themselves or in combination with the roots, herbs and barks of other plants.

G. latifolium, is believed to have its origin in Southern Nigeria where its use as both medicinal material and food ingredient pre-dates historical records. It is widespread in tropical rainforest of West African countries such as Nigeria, Ivory Coast, Sierra Leone, Ghana and Senegal. Known as "utazi" in Igbo, and "orokeke" in Yoruba, G. latifolium (Asclepiadeceae) has been used in Nigerian herbal practice to treat diabetes mellitus and malaria infections. G. latifolium is 
an indigenous herb that is bitter and has many folkloric attributes as a healing herb (Seitz and Stickel, 2006). The stems are somewhat soft and hairy, and yield milky latex or exudates (Ihesie, 2015).

While suggesting that it could have some augmentary or protective effect against certain hepatocellular injury, Etim et al. (2008), affirmed that leaves of $G$. latifolium have protective role against diabetes, hypertension, stomach upsets and pains, malaria and typhoid fever. Meanwhile, Ugochukwu et al. (2003) reported that the ethanolic extract of $G$. latifolium leaves possess antioxidant activity. Ihesie (2015) observed that in many local "joints", where people enjoy Nigerian delicacies like isiewu, nkwobi and abacha/ugba (African salad) with palm wine or beer, the leaves are usually added to these delicacies to help prevent drunkenness or hangover. They are believed to neutralize the intoxicating effects of the alcoholic drinks.

The leaves of G. latifolium, examined by Imo and Uchegbu (2015), showed the presence of different types of alkaloids, flavonoids, total phenolic compound, lignan, terpenes, sterol, allicin, hydroxycinnamic acids, saponin and carotenoid; with some in an appreciable concentrations. Egbung et al. (2011) reported the presence of phytochemicals (tannins, saponins, alkaloids, flavonoids and hydrocyanide), mineral elements $(\mathrm{Cr}, \mathrm{Cu}, \mathrm{Se}, \mathrm{Zn}$ and $\mathrm{Fe})$ and vitamins $(\mathrm{A}, \mathrm{C}$, riboflavin, niacin and thiamine) in the root bark and twig extracts of $G$. latifolium. These results showed that $G$. latifolium leaves possess a wide variety of phytochemicals which can be of pharmacological implication, both in terms of prevention and treatment/management of diseases.

Piper guineenseis a plant native to West Africa and located across the various geopolitical zones in Nigeria, as well as other parts of Africa. P. guineense (also called African pepper, Ashanti pepper, Benin pepper, false cubeb, Guinea cubeb, uziza and Guinea pepper) belonging to the family Piperaceae are semi-cultivated in countries such as Nigeria where the leaves and seeds are used as flavouring agent. Its leaves and seeds are widely used as local spices due to their aromatic and pungent scent.

Etukudo (2003) remarked that $P$. guineenseis an important African medicinal plant. The seeds are revulsive, anthelmintic, carminative, appetizer, stomachic, styptic, vulnerary, calefacient, bronchodilator, digestive and counterirritant. Both the seeds (berries) and leaves are essential ingredients for the preparation of soup and yam porridge for women that gave birth newly in many parts of Nigeria; and Morah et al. (2016) observed that $P$. guineense imparts heat and a spicy pungent aroma to classic West African soups. Like other members of the pepper family, Ashanti peppers contain 5-8\% of the chemical piperine which gives them their hot taste, and they contain large amounts of beta-caryophyllene as well as significant proportions of myristicin, elemicin, safrole and dillapiol, Morah et al. (2016).

Haeckel (1981) reported that the seed and leaf extracts are capable of exhibiting a depolarizing neuromuscular activity in a concentration related manner; while Ali et al. (2015) reported that the leaf and seeds of $P$. guineense exhibited antiparasitic, antibacterial and antifungal activity. Moreover, according to Iqbal et al. (2006) leaves of P. guineense have been used in traditional medical practices for the treatment of respiratory diseases and for correcting female fertility problems; whereas Mfon et al. (2011) reported that $P$. guineense seeds have been used as aphrodisiac.

Objectives of the Study: This study compared the effects of the aqueous extracts of the plant samples on the serum concentrations and activities of the following liver and kidney biomarkers: alkaline phosphatase (ALP), alanine transaminase (ALT), aspartate transaminase (AST), albumin (ALB), urea, creatinine, sodium, potassium, chloride and bicarbonate.

Justification for the Study: The plant samples used are important staple food and are used in many medicinal preparations either in isolation to each other or in combination. To study their separate and collective dosedependent effects on the liver and kidney biomarkers of mammals is therefore very imperative. Ascertaining the effects of these extracts on the liver and kidney which are involved in the metabolism and extraction of these extracts is therefore of very importance.

Limitation of Study: The study did not examine the effects of the individual phytochemicals present in these plant materials on the test animals so as to clarify which principle in the plant extracts exerts what effect. Also, the study did not evaluate the effects of ethanolic, methanolic or tetrachloromethane extracts on the test animals; nor did it test the remediating effects of the plant extracts on any disease state. Moreover, the study did not extend to histopathological examinations on the liver and kidneys to check their health and integrity.

\section{MATERIALS AND METHODS}

Plant Materials: Fresh leaves of Gongronema latifolium and seeds of Piper guineense were purchased from Nkwo IgboUkwu market in Aguata Local Government Area, Anambra State; and were identified at the Department of Biological Sciences of Chukwuemeka Odumegwu Ojukwu University. These materials were sorted, washed, air-dried at room temperature and ground into powder. The powder was stored at room temperature until when needed.

Experimental Animals: The experimental animals were all male albino rats of 5-7 weeks old with average weights of 160 $\mathrm{g}$, and were acclimatized for 7 days before administration. The animals were allowed food and water ad libitum, and standard laboratory protocols for animal studies were maintained.

Reagents: Reagents used for all the assays were commercial kits and products of Teco Diagnostics, USA.

Equipment/Instruments: The following instruments were employed in the research work: Water bath (Gallenkamp, England), conical flasks (Pyrex, England), Adjustable micropipette (Perfect, U.S.A.), Refrigerator (Kelvinator, 
Germany), Test tubes (Pyrex, England) and Digital Spectrophotometer (Systonic, Germany).

Methodology: Extraction of Gongronema latifolium Leaves and Piper guineense Seed was by the modified method of Abubakar et al. (2010).

Experimental Design and Treatment of Animals: The animals were randomly selected and grouped into 6 groups of 5 animals each; and were treated as follows:

Group1 (control): Food and wateronly,ad libitum.

Group 2: Food and water ad libitum, and administered $20 \mathrm{mg}$ of $G$. latifoliumleaves extract/kg b.w.

Group 3: Food and water ad libitum, and administered 20 mgof $P$. guineense seeds extract $/ \mathrm{kg}$ b.w.

Group 4: Food and water ad libitum, and administered 2:18 milligram of $G$. latifoiumleaves extract and $P$. guineense seeds extract $/ \mathrm{kg}$ b.w.

Group 5: Food and water ad libitum, and administered 10:10of G. latifoliumleaves extract and $P$. guineense seeds extract/kg b.w.

Group 6: Food and water ad libitum, and administered 18:2 milligram of $G$. latifoliumleaves extract and $P$. guineense seeds extract $/ \mathrm{kg}$ b.w.

30 animals were used, and were treated daily for 21 days orally, using oral intubation syringe.

The animals were sacrificed on the $22^{\text {nd }}$ day after overnight starving via incisions into their thoracic cavity, and blood collected by heart aorta puncture using $10 \mathrm{~mL}$ hypodermic syringe. The serum was obtained by centrifugation, and stored in a refrigerator at between $0-5^{\circ} \mathrm{C}$ until when needed.

\section{Biochemical Analysis:}

Alkaline Phosphatase: This was determined by kinetic assay method of Werner and Igbal (1990) which measures the rate of hydrolysis of various esters - in particular, pNitrophenol phosphate (p-Npp).

Alanine transaminase: Alanine transaminase was determined by the UV method of Wroblewski and LaDue (1956). This method was based on the oxidation of reduced Nicotinamide Adenine Dinucleutide, NADH, by lactate dehydrogenase (LDH).

Aspartate Transaminase: This was determined using the modified colorimetric method as ddescribed by Doumas and Briggs (1969).

Albumin: Albumin determined by the azo dye methods described by Bartholomew and Delany (1964).
Creatinine: This was based on the reaction of creatinine with alkaline picrate as described by Heinegard and Tiderstrom (1973).

Urea (BUN): The Berthelot reaction (Tobacco et al., 1979) was used for the determination of urea (BUN).

Sodium: This was determined by the method of Trinder (1951).

Potassium: This was determined by the method of Terri and Sesin (1958).

Chloride: This was determined by the colorimetric method of Skeggs and Hochestrasser (1964).

Bicarbonate: This was determined by spectrophotometric procedures which measures $\mathrm{CO}_{2}$ concentration enzymatically, and is a modification of the method of Forrester and Roger (1976).

Statistical Analysis: Results were expressed as mean and standard deviation (Mean $\pm \mathrm{SD}$ ).

Statistical analyses were performed on data generated from the study using Statistical Package for Social Sciences (SPSS) software for windows, version 20.

One way analysis of variance (ANOVA) was used to compare the mean result of different sample groups. Correlation analysis was done on data collected to establish the relationship of data with one another. Statistical significance was observed $\mathrm{P} \leq 0.05$.

\section{RESULTS}

Effects of aqueous extracts of $P$. guineense seeds and $G$. latifolium leaves on serum activities of liver enzymes of male albino rats are shown in Figure 1.

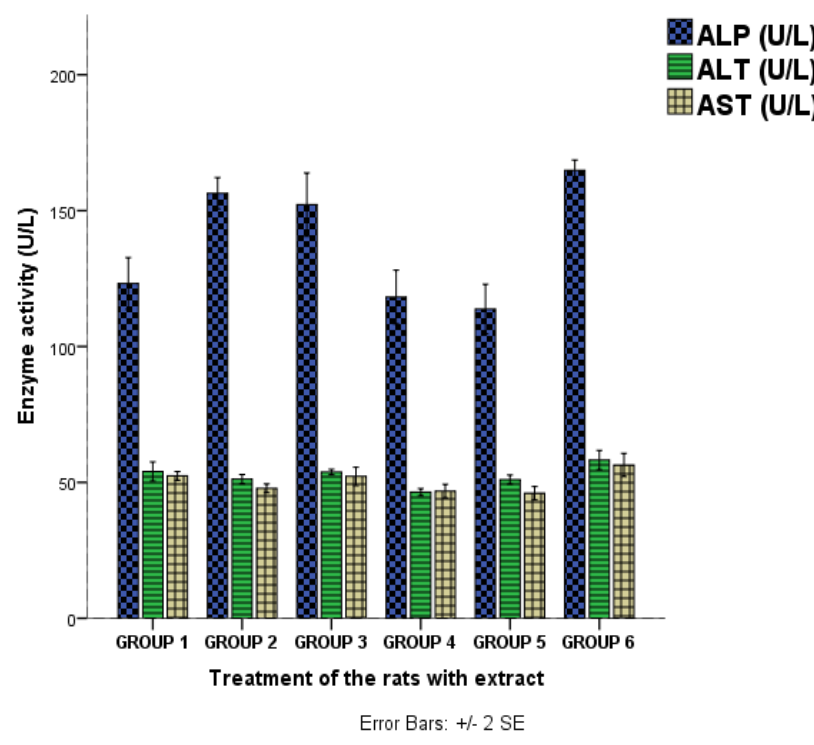

Figure 1: Effects of Aqueous Extracts of P. guineense Seeds and G. latifolium Leaves on Serum ALT, ALP and ASP of Male Albino Rats. 
Effects of aqueous extracts of $P$. guineense seeds and $G$. latifolium leaves on serum albumin of male albino rats are shown in Figure 2.

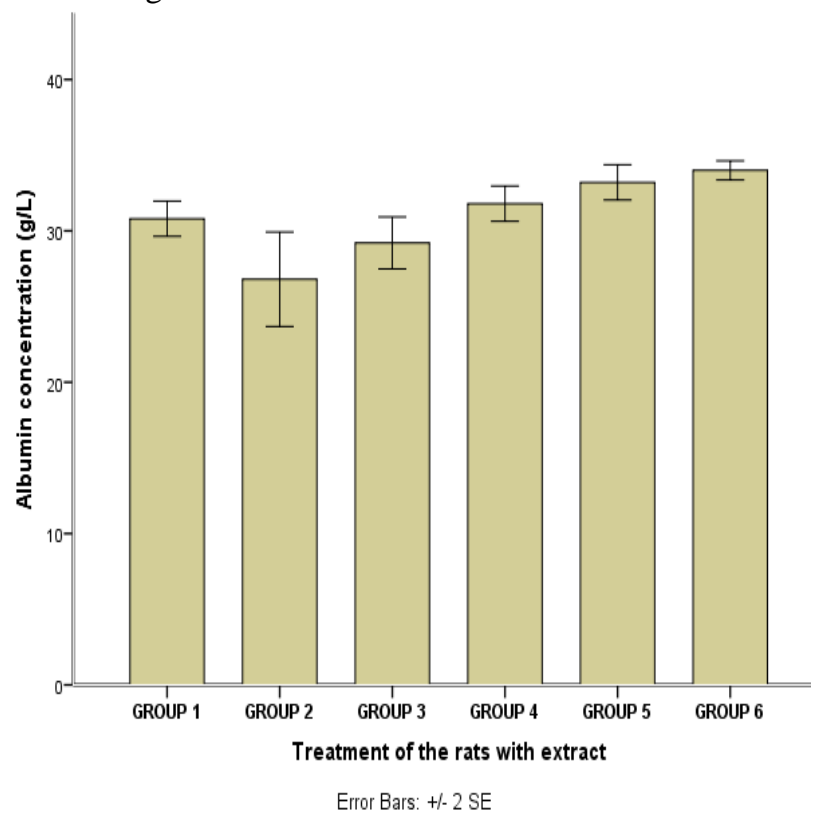

Figure 2: Effects of Aqueous Extracts of $P$. guineense Seeds and G. latifolium Leaves on Serum Albumin of Male Albino Rats.

Effects of aqueous extracts of $P$. guineense seeds and $G$. latifolium leaves on serum sodium ion and potassium ion concentrations of male albino rats are shown in Figure 3.

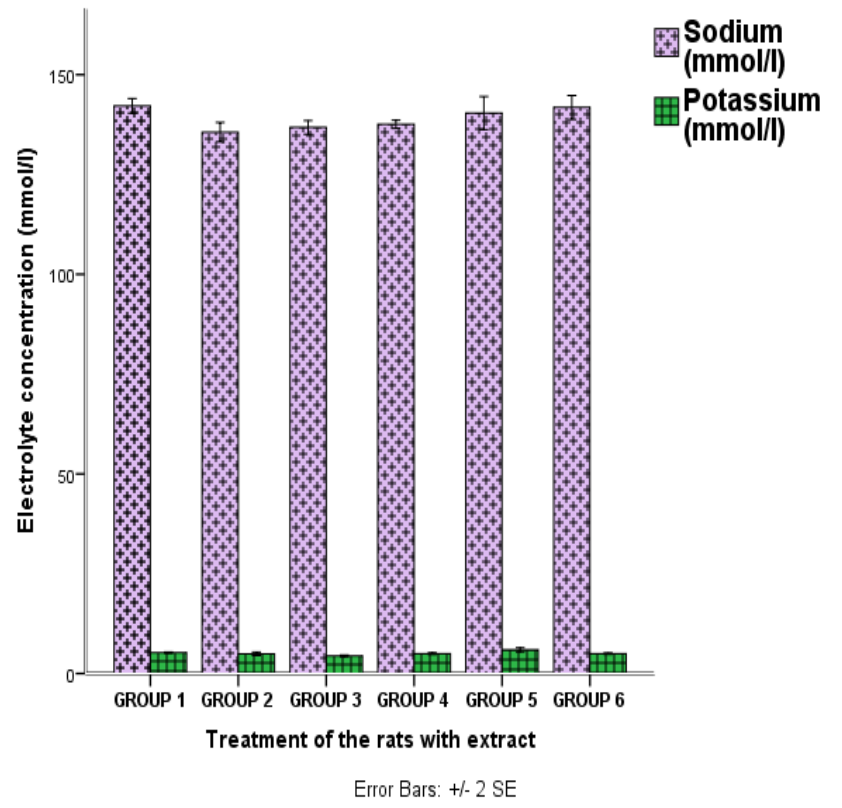

Figure 3: Effects of Aqueous Extracts of $P$. guineense Seeds and G. latifolium Leaves on Serum Sodium Ion and Potassium Ion Concentration of Male Albino Rats.

Effects of aqueous extracts of $P$. guineense seeds and $G$. latifolium leaves on serum chloride ion and bicarbonate ion concentrations of male albino rats are shown in Figure 4.

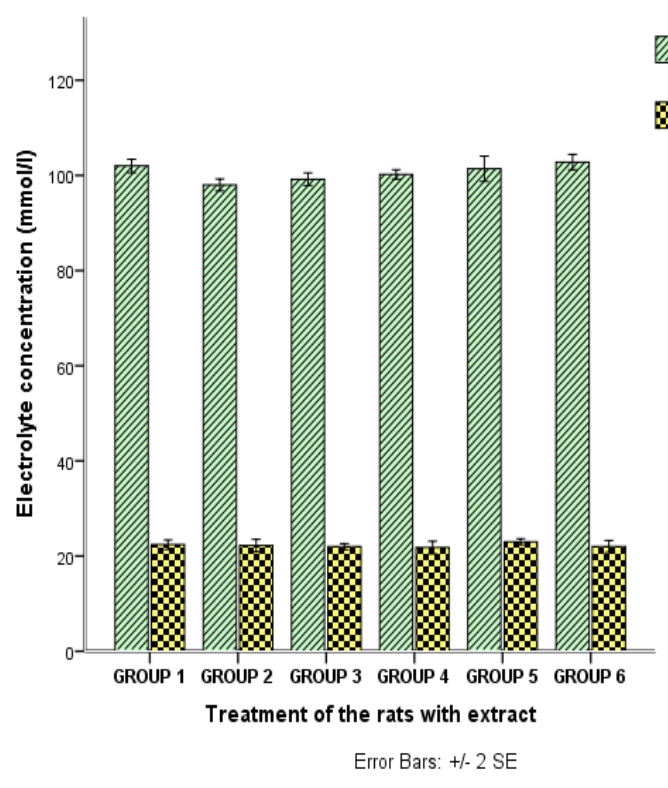

Figure 4: Effects of Aqueous Extracts of $P$. guineense Seeds and $G$. latifolium Leaves on Serum Chloride Ion and Bicarbonate Ion Concentrations of Male Albino Rats.

Effects of aqueous extracts of $P$. guineense seeds and $G$. latifolium leaves on serum creatinine and urea concentration of male albino rats are shown in Figure 5.

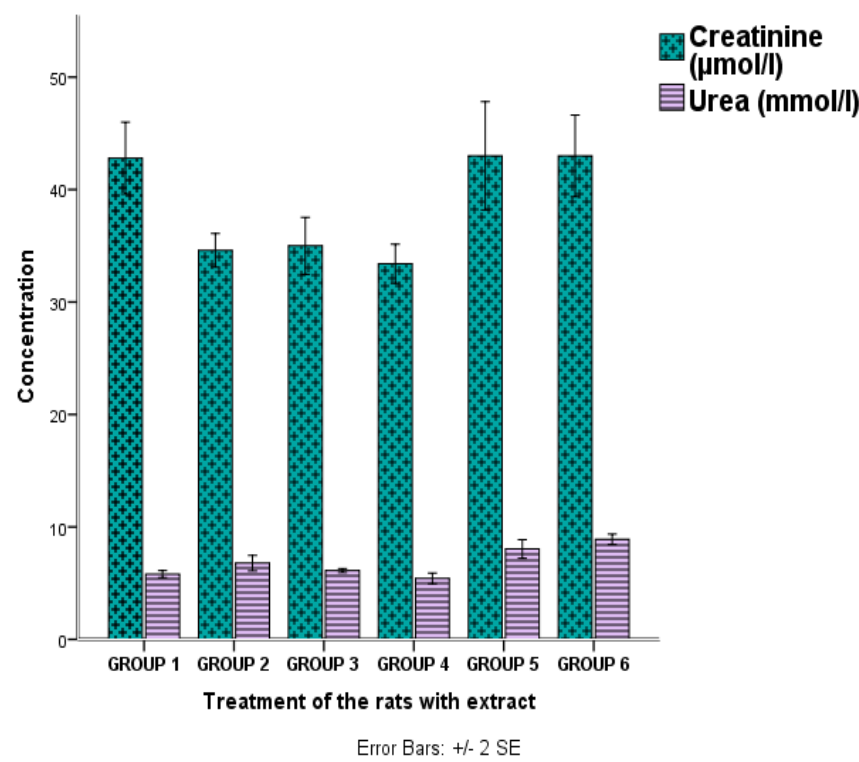

Figure 5: Effects of Aqueous Extracts of P. guineense Seeds and $G$. latifolium Leaves on Serum Creatinine and Urea Concentrations of Male Albino Rats.

\section{DISCUSSION}

The study compared the effects of acute (21 days) administration of aqueous extracts of Gongronema latifolium leaves and Piper guineense seeds, administered separately and in combination at various concentrations, on the following liver and kidney parameters: alkaline phosphatase (ALP), alanine transaminase (ALT), aspartate transaminase (AST), albumin (ALB), electrolytes ( $\mathrm{Na}, \mathrm{K}, \mathrm{Cl}$ and $\mathrm{HCO}_{3}{ }^{-}$), urea and creatinine. 
The increase or decrease (change) in the concentrations and activities of the various parameters assayed in the treated groups were compared to those of the control group; and the differences were accepted as significant at $\mathrm{p}<0.05$ and $95 \%$ confidence interval for mean. The entire study assessed together is beyond mere academic exercise as it opens up on the very important issue of the importance of the test samples on the health, integrity and overall functions/physiology of the key internal organs of present interest - the liver and the kidneys.

The results show that the test samples are largely not of much deleterious effects to the organs under study - particularly the liver; although a few significant observations are in the negative. The few significant results obtained - particularly with regards to the kidney - can go a long way in their overall implications to the life and wellbeing of the individuals that cash in on them for their medicinal and nutritional needs, and these findings are in good standing with many of the works sited in the literature review - and this will help consumers of the samples studied and tradomedicinal practitioners make more important decisions.

Liver Biomarkers: Administration of 20 milligram of $G$. latifolium per kilogram body weight of test animals (group2) showed a significant increase $(\mathrm{p}<0.05)$ in ALP activity when compared to the control. Similar (significant) result was obtained with group 3, compared to group1 (the control group), which was treated with 20 miligramof $P$. guineense aqueous seeds extract, per kilogram body weight of test animals. The same observation was made in group $6-$ administered with a mixture of $G$. latifolium and $P$. guineense samples at the ratio of 18:2 respectively. That is to say, there was observed significant increase $(\mathrm{p}<0.05)$ in ALP activities in groups 2, 3 and 6; whereas groups 4 and 5 showed no significant $(p>0.05)$ decrease in ALP activity, compared to group 1. It is of interest that the separate administration of the two samples - Groups 2 and 3 - showed significant increase in ALP activity, whereas in combined form, in Groups 4 and 5, there was no observed change in the serum ALP activity; only for Group 6 (administered with 18:2 G. latifolium and $P$. guineense extracts) still showed a significant increase in serum ALP activity.

ALT showed no significant ( $\mathrm{p}>0.05)$ change in activity in groups 2, 3 and 5, while a significant $(\mathrm{p}<0.05)$ decrease was observed in group 4 (administered with ratio 2:18 G. latifolium and P. guineense extracts); and group 6 showed no significant ( $p>0.05$ ) change in the activity of same, compared to group 1. On the other hand, AST showed no significant change $(p>0.05)$ in serum activity across the groups, compared to group 1 .

Moreover, all the groups showed no significant change in serum albumin concentration, except group 2 which showed a significant decrease in serum albumin concentration - a phenomenon known as hypoalbuminaemia (Anderson, 2000).

Although the above parameters mark for the liver health, integrity and functions, yet ALP and albumin are not very specific to the liver, but rather also mark for the kidney as well as other mammalian organs. Moreover, the parameters that more specifically mark for the liver - AST and ALT were largely insignificant in their changes, relative to group 1.

This lightly suggests that aqueous extracts of the plant samples may have caused some level of hepatic injury in the test animals. However, putting group 4 result for ALT into consideration, in which there is a significant decrease in serum ALT activity, compared to group 1, and extending these observations further to other internal organ(s), there is a strong suggestion indicating that the aqueous extracts of the plant samples do not significantly contain some potent pharmacological agents that are antagonistic to the liver; rather the observations indicate that they contain potent pharmacological agents that are deleterious to other organs of the body that these parameters mark for. There is no evidence to conclusively infer that the samples exhibited hepatotoxic effect; but a strong evidence (group 4, ALT) strongly suggests hepatic remedy.

The increase in serum ALP activity in the test groups 2, 3 and 6 could be attributed to a toxicity effect in any other organ other than the liver. As noted, ALP is as well a marker for bone health (as well as other organs such as the kidney) Reiss et al., 1996; Friedman et al., 1996), and is not even an ideal marker for the liver. This was similarly noted by Kochmar and Moses (1976), in which they remarked that Alkaline Phosphatase (ALP) is distributed in almost every tissue in the body. They as well noted that serum ALP levels are of interest in the diagnosis of hepatobiliary disorder. In addition, Kaplan and Righetti (1955) reported that moderate elevations of ALP (not involving the liver or bone) may be attributed to Hodgkin's disease (a malignant disease of the lymphatic tissues typically causing painless enlargement of the lymph nodes, liver, and spleen) congestive heart failure, and abnormal bacterial infection. Kaplan (2012) also remarked that ALP are present in many human tissues, including bone, intestine, kidney, liver, placenta and white blood cells where its major function is transmembrane transport (Cerik etal. 2009) - and so, damages these tissues cause the release of ALP into the bloodstream. Moreover, as reported by Damera et al. (2011), elevated serum activity of ALP has been associated with Chronic Kidney Disease (CKD). They also showed that elevated serum activity of ALP may predict mortality independent of bone metabolism and liver function tests in CKD. Elevation also occurs in the third trimester of pregnancy. Still on reports in support of the opinion that the observed elevation in serum ALP activity, relative to control, is not sufficient to infer hepatotoxicity, since the other two, and more direct, parameters - AST and ALT - did not show any significant increase in serum activity: Khan et al. (2015) reported an observed higher serum ALP activity in obese than non-obese - indicating that positive weight change could as well be implicated in the observed increase in serum ALP activity.

The increase in ALP serum activity, therefore, could mean that the test samples were injurious to the bones, the heart and/other organs (Friedman et al., 1996; Reiss et al., 1996) seeing also that the more specific marker enzymes (ALT and AST) (Ghouri et al. 2010; Wang et al, 2012) did not show any significant increase in serum activities. Even further than this, it could be a pointer that the samples elicited 
hepatobiliary malignancy in the test animal - which obviously was not observed in the control. Moreover, the test samples could be inferred as having hepatoprotective effect, seeing that a significant $(\mathrm{p}<0.05)$ decrease of ALT (a more specific marker for liver health and functions (Ozer et al. $2008)$ activity in group $4(2: 18 \mathrm{mg} / \mathrm{kg}$ b.w. of $\mathrm{G}$. latifoium and $P$. guineense), and all the other groups (except 6) showed non-significant decrease in ALT and AST serum activities. It therefore strongly puts to the fore the suggestion that the test samples, both collectively and individually helped the health, physiology and integrity of the liver; while also suggesting that they were deleterious to the other organs for which ALP marks.

As for albumin, there is a significant $(\mathrm{p}<0.05)$ decrease in its serum concentration in group 2, while the other groups showed non-significant ( $p>0.05)$ increase in albumin concentration, with the exception of group 3 . That is to say, Group 2 showed a significant $(\mathrm{p}<0.05)$ decrease in albumin concentration, while group 3 showed a non-significant ( $p>0.05$ ) decrease in albumin concentration; groups 4,5 and 6 show a non-significant $(p>0.05)$ increase in albumin concentration, all compared to group 1 , as was observed from the analyzed result. However, the significant decrease in albumin concentration, as observed in group 2 is not sufficient to infer hepatic injury; since albumin is equally a marker for kidney health and functions/integrity (Anderson, 1982). This is a good pointer that aqueous extract of $G$. latifolium is an antagonist to the health/integrity and functions of the kidney - it is implicated in renal toxicity.

However still, the fact that some separate and combined groups showed significant increase in ALP activity, whereas others did not, suggests that caution should be employed in the use of the plant samples, separately and collectively, particularly as medicinal preparations. This is because Lange et al. (1982) suggested that significant $(\mathrm{p}<0.05)$ increase in serum ALP activity could be a pointer to liver disease/disorder - being aware of other possibilities, as already noted. This does not mean to deter from its nutraceutical applications, rather it underscores the notion in pharmacology that "concentration differs remedy from toxins".

\section{Kidney Biomarkers}

There is a significant decrease in serum $\mathrm{Na}^{+}$concentration observed in group 2, as compared to group 1. This condition of low serum $\mathrm{Na}^{+}$concentration is known as hyponatraemia (Lee et al., 2014), and can manifest as cellular oedema which can affect the central nervous system and causes depression and cerebral oedema (Clement et al., 2015); and can manifest, in humans, as decreased ability to think, headache, nausea and confusion, as well as poor balance, seizures and coma (Henry, 2015). These all show that hyponatraemia is of serious health implication to mammals, and are either as a result of impaired kidney functions or low sodium intake in diet. In the case of this work, where it is observed in group 2, when compared to group 1; it can be inferred that the administration of $G$. latifolium leaf extracts impaired with the kidney functions - particularly selective reabsorption - and thus the observed condition. This significant $(p<0.05)$ decrease in the serum concentration of sodium ions corresponds with a significant decrease in chloride ions in group $2(20 \mathrm{mg} / \mathrm{kg}$ b.w. G. latifolium) compared to group 1 while the decrease observed in the other groups are nonsignificant $(\mathrm{p}>0.05)$. This is a strong indication that the sample administered, aqueous extract of G. latifolium, has a negative effect on the serum electrolyte balance of the test animals. By implication, the sample contains some phytochemicals and pharmacological principles that negatively affect renal health and functions.

Extending this to the effects observed earlier with ALP and albumin, in which there is increase in the activity of the former and concentration of the latter, it further suggests that the test sample, G. latifolium, has a deleterious effect on the renal health and functions when ingested continuously over a period of time. This inference is so because ALP and serum albumin are two important biomarkers for the renal integrity, functions and health, as noted by Friedman et al. (1996), Reiss et al. (1996) and Anderson (1982). On the other hand, $P$. Guineense seems ton as well affect the health and functions of the kidney adversely, and so serum electrolyte balance, as seen in the other groups, just that the effects are non-significant $(\mathrm{p}>0.05)$.

Moreover, a combination of the two test samples, $G$. latifolium and $P$. Guineense, as observed, gave rise to a significant $(\mathrm{p}<0.05)$ rise in serum urea concentration (a condition known as uraemia/azotomia), compared to group 1, as observed in groups 5 and $6(10: 10 \mathrm{mg} / \mathrm{kg} \mathrm{b.w.} \mathrm{of} G$. latifolium and $P$. guineense, and $18: 2 \mathrm{mg} / \mathrm{kg}$ b.w. of $G$. latifolium and $P$. guineense) - there was a similar increase observed in the groups treated separately ( 2 and 3 ), just that the increase are non-significant. That is to say, compared to group 1, groups 2 and 3 showed a non-significant $(p>0.05)$ increase in urea concentration, group 4 showed a nonsignificant decrease; while groups 5 and 6 showed a significant $(\mathrm{p}<0.05)$ increase in serum urea concentration. Uraemia, as observed in Bishop et al. (1962), is the terminal clinical manifestation of renal failure, and is marked by very high serum urea concentration. Similarly, Burtis et al. (1965) remarked that uraemia is due to prolonged inadequate excretory, regulatory and endocrine functions of the kidneys.

This suggests that the kidneys were better off (healthier) in handling/excreting urea when the test samples were administered separately than when combined in food and medicinal preparations. Also, continuous administration of the samples is as well deleterious to the integrity and functions of the kidneys (Henry et al., 1974).

Strangely though, while groups 5 and 6 showed no significant decrease in the serum concentration of creatinine, the groups with separate administrations, groups 2, 3 and 4 showed significant $(p<0.05)$ decrease in serum creatinine concentration, compared to group 1 . This indication is so as an unhealthy kidney condition is expected to be associated with elevated serum creatinine level. This apparent discrepancy was well explained by Bjornsson (1979), in which he explained that although serum creatinine concentration is a marker for kidney functions and health, that it is more specific for glomerular filtration rate (GFR). This goes on to suggest that, while the samples are deleterious to the kidney health, integrity and functions, it does not affect 
glomerular filteration rate. Also, several other studies have suggested serum creatinine to be a poor marker of renal health and function (Shemesh, et al., 1985). However, while it appears that low serum creatinine concentration is not much of a sign for kidney malfunction, Maanasi (2017) says otherwise, rather implicating kidney malfunction, alongside age, low muscle mass, protein deficiency and pregnancy as causes.

\section{CONCLUSION}

From the observations/results, it can be concluded that the aqueous extracts of the test samples, Gongronema latifolium leaves and Piper guineense seeds, are of no practical deleterious effects to the functions of the liver of albino rats - no evidence of hepatotoxicity - either singly or in combination. However, there are evidences to support that they are of adverse effects to the renal health and functions. Moreover, the test sample G. latifolium, as observed, resulted in a negative electrolyte balance - with sodium ions and chloride ions being the most affected ions/electrolytes - and thus is deleterious to the kidney. Also, a combination of the two test samples are deleterious to the functions of the kidneys, as marked by the negative urea clearance. Moreover, the test samples, as can be inferred from their effects on serum ion balance, may as well be implicated in kidney hormonal imbalance - the minerlocorticoids. Caution should therefore be taken while administering these test samples, particularly in traditional medicine preparations, especially when taken in medicinal mixtures.

\section{REFERENCES}

Abubakar, S.M. and Sule, M.S. (2010). Effect of Oral Administration of Aqueous Extract of Cassia Occidentalis L. Seeds on Serum Electrolytes Concentration in Rats. Bayero Journal of Pure and Applied Sciences, 3 (1): $183-187$.

Ali, F. U., Ominyi, M. C., Nwankwo, O. V., Ibiam, U. A. and Ogbansi, M. E. (2015). Comparative Effect of Ethanolic Extracts of G. latifolium leaves and $P$. Guineense seeds on Blood Electrolytes in Ethanol Exposed Wistar Rats. Biochemistry and Analytical Biochemistry, 4: 179-185.

American Society for Testing and Materials (2001). Standard test method for estimating acute oral toxicity in rats. American society for testing and materials, Philadelphia, USA. Pp.55-62.

Anderson, C. F. (2000). Elevated Serum Albumin Concentration: Causes and Consequences. Mayo Clin. Poc. 57:181.

Bartholomew, R., and Delany, A. (1964). Proc. Australian Assoc. Clin. Biochem. P. 164

Bishop, M. L., Fody, E. P. And Schoeff, L. E. (1962). Clinical Chemistry: Techniques, Principles, Correlations. $6^{\text {th }} e d$. Lippincott Williams and Wilkins. p. 268.

Bjornsson, T. D. (1979). Use of Serum Creatinine Concentration to Determine Renal Function. ClinPharmacokinet, 4 (3): 200-222.

Burtis, C. A. Ashwood, E. R. and Brun, D. E. (1965). Textbook of Clinical Chemistry and Molecular Diagnostics. ( $5^{\text {th }}$ ed.). Elsevier Saunders. P. 1554.

Celik, H., Tosun, M., Cetinkaya, M. B., Bektab, A. and Malatyalyod, I. U. (2009). Markedly Elevated Serum Alkaline Phosphatase Level in an Uncomplicated Pregnancy. The J. of Maternal-Fetal and Neonatal Med., 22 (8): $705-707$.
Clement, O., Benjamin, K. S. and Elliot, E. D. (2015). Changes in Potassium and Sodium Concentration in Stored Blood. The Pan African Med. J., 20: 236.

Damera, S., Raphael, K. L., Baird, B. C., Cheung, A. K., Greene, T. and Beddhu, S. (2011). Serum Alkaline Phosphatase Levels Associated with Elevated Serum C-reactiveProtein in Chronic Kidney Disease. Kidney Int'l., 79 (2): $228-233$

Doumas, B. and Briggs, H.G. (1969). Determination of Serum Aspartate Transaminase Activity by Colorimetric Method. Clin. Chem. Acta, 25:75.

Egbung. G. E., Atangwho. I. J., Iwara, I. A. and Eyong, U. E. (2011). Micronutrient and Phyto-chemical Composition of Root Bark and Twig Extracts of Gongronema latifolium. Journal of Medicine and Medical Sciences, 2(11):1185-1188.

Etim, O. E., Akpan, E. J. and Usoh, I. F. (2008). Hepatotoxicity of Carbon Tetrachloride: Protective Effect of Gongronema latifolium.Pak. J. Pharm. Sci., 21(3): 268-274.

Etukudo, I. (2003). Ethnobotany: Conventional andTraditional Uses of Plants. The verdict Press, Uyo, Nigeria. P. 108.

Forrester, V. and Roger, L. (1976). Enzymatic Determination of Serum Bicarbonate Concentration. Clin Chem., 22: 243-245.

Friedman, L. S., Martin, P. and Munoz, S. J. (1996). Liver Function Tests and the Objective Evaluation of the Patient with Liver Disease. In: Hepatology: a Textbook of Liver Disease. Philadelphia, WB Saunders. 791833. Google Scholar.

Ghouri, N., Preiss, D. and Sattar, N. (2010). Liver enzymes, non-alcoholic fatty liver disease, and incident cardiovascular disease: A narrative review and clinical perspective of prospective data. Hepatology, 52 (3): 1156-1161.

Haeckel, R. (1981). Assay of Creatinine in Serum, with Use of Fuller's Earth to Remove Interferents. Clin. Chem., 27: 178- 183

Heinegard, D. and Tiderstrom, A. (1973). Determination of Serum Creatinine by Direct Colorimetric Method.Clin. Chem. Acta, 43:305.

Henry, D. A. (2015). In The Clinic: Hyponatremia. Annals of int. Med., 163 (3): $1-19$

Henry, J.B., Todd, S.D. (1974). Clinical Diagnosis and Management by Laboratory Methods.16th ed. W. B.Saunders and Co., Philadelphia, PA. p.260.

Ihesie, G.C.(2015). Health Benefits of Gongronema latifolium (utazi) m.guardian. ng/ features /health/health-benefits-of-gongronema-latifoliumutazi.

Imoh, C. and Uchegbu, F. O. (2015). Phytochemical Analysis of GongronemalatifoliumBenth Leaf Using Gas Chromatographic Flame Ionization Detector. Int'l J. Chem. and Biomol. Sc.1(2): 60-68. Available online at: http://www.aiscience.org/journal/ijcbs.

Iqbal, A., Khalil, I. A., Ateeq, N. and Khan, M. S. (2006). Nutritional quality of important food legumes. Food Chemistry, 97: 331-335.

Kaplan, M. N. (2012). Alkalline Phosphatase. New England J. Med., 286 (4): $200-202$.

Kaplan, M. W. and Righetti, A. (1955). Induction of Rat Liver Alkaline Phosphatase. J. Clin. Inv., 34: 126

Khan, A. R., Awan, F. R., Najam, S. S., Islam, M., Siddique, T. and Zain, M. (2015). Elevated Serum Level of Alkaline Phosphatase in Obesity. $J$. Pakistan Med. Assoc., 65 (11): 1182 - 1185.

Kochma, J. F. and Moses, D. W. (1976). Fundamentals of Clinical Chemistry. N. W. (ed). W. B. Saunders and Company, Philadelphia, PA. p. 604.

Lange, P. H., Milan, J. L., Stigbrand, T., Vescella, R. L., Ruoslahti, E., and Fishman, W. H. (1982). Placental ALP as a Tumor Marker for Seminoma. Cancer Res. 42 (8): 3244-3247. 
Lee, J. J., Kilonzo, K., Nistico, A. and Yeates, K. (2014). Management of Hyponatremia. Canadian Med. Assoc. J., 186 (8): E281-E286.

Maanasi, R. (2017). Five Causes and Remedies for Low Creatinine Levels. www.stylecraze.com/articles/causes-and-remedies-for-low-creatininelevels.

Mfon, I. A., Item, J. A., Amabe, A., Victor, A. F. and Anozeng, O. I. (2011). Effect of Combined Leaf Extract of Vernociaamygdalina (Bitter leaf) and Gongronema latifolium (utazi) on B-cell of Streptozon Induced Rats. British Journal of Medicine and Medicinal Resource, 1: 24-34.

Morah F. N. I., Ekanem A. P. and Edubio V. O. (2016).Toxicity of Piper guineenseberry to Clarias gariepinus. Edorium J Toxicol., 1:1-4.

Ozer, J., Ratner, M., Shaw, M., Bailey, W. andSchomaker, S. (2008). The current state of serum biomarkers of hepatotoxicity. Toxicology, 245: 194 205 .

Reiss, I., Inderrieden, D., and Kruse, K. (1996). Measurement of Skeletal Specific Alkaline Phosphatase in Disoredrs of Calcium Metabolism in Childhood. MonatsschriftKinderheilkunde, 144 (9): 885-890.

Seitz, H.K. and Stickel, F. (2006). Risk Factors and Mechanisms of Hepatocarcinogenesis with Special Emphasis on Alcohol and Oxidative Stress. Biological Chemistry, 387:349-360

Shemesh, O., Golbetz, H.V., Kriss, J.P. and Myers B.D. (1985). Limitations of creatinine as a filtration marker in glomerulopathic patients. Kidney Int., 28: $830-838$.

\section{How to cite this article}

Lukong, C. B., Ifemeje, J. C., Chukwuka, D. T. and Onah, C. (2018). Effects of aqueous extracts of Gongronema latifolium leaves and Piper guineense seeds on liver and kidney biomarkers of albino rats. Tropical Journal of Applied Natural Sciences, 2(2): 26-33. Doi: https://doi.org/10.25240/TJANS.2018.2.2.04.
Skeggs. L.T. and Hochstrasser, H.C. (1964). Colorimetric Method for the Determination of Chloride and Bicarbonate. Clin. Chem., 10:918.

Terri, A. E. and Sesin, P. G. (1958). The Principle for Determining Serum Potassium Concentration. Am. J. Clin. Path., 29:86.

Tietz, N. W. (1996). Fundamentals of Clinical Chemistry. $4^{\text {th }}$ ed. Saunders,

Tobacco A. (1979). The Use of Berthelot Reaction in Determining Serum Urea Concentration.Clin Chem., 25:336.

Trinder, P. (1951). Serum Sodium Concentration Determination. Analyst, 76:596

Ugochukwu, N. H., Babady, N. E., Cobourne, M. and Gasset, S. R. (2003). The Effects of Gongronema latifolium Leaf Extracts on Serum Lipid Profile and Oxidative Stress in Hepatocytes of Diabetic Rats. J. Biosc., 8: 1- 5.

Wang, C. S., Chang, T. T., Yao, W. J., Wang, S. T. and Chou, P. (2012). Impact of Increasing Alanine Aminotransferase Levels within Normal Range of Incident Diabetes. J. Formosan Med. Assoc. - Taiwan, Yi Zhi., 111 (4): 201-208.

Werner, P. V. and Igbal, W. S. (1990). Kinetic Determination of Alkaline Phosphatase Activity Based on Hydrolytic Cleavage of the P-F Bond in Monofluorophosphate and Fluoride Ion elective Electrode. Anal Biochem. 191 (1): 127-132

Wroblewski, F. and LaDue, J.S. (1956). Proc. Soc. Exper. Biol. and Med. 91:569. The Scandinavian Society for Clinical Chemistry and Physiology: Recommended Methods for the Determination of Four Enzymes In Blood (1974). Scand. J. Clin. Lab. Invest., 32:29. Philadelphia. p. 984.

Licensed under a Creative Commons Attribution 4.0 International License 